\title{
MIR9-1 Pre-miRNA
}

National Cancer Institute

\section{Source}

National Cancer Institute. MIR9-1 Pre-miRNA. NCI Thesaurus. Code C82735.

MIR9-1 pre-miRNA is an oligonucleotide that is encoded by the human MIR9-1 gene and has a role in the regulation of gene expression. 